Egyptian Journal of Rabbit Science, 22 (1) 41-54(2012)

\title{
PERFORMANCE OF GROWING RABBITS FED ON SOME AGRO- INDUSTRIAL BY-PRODUCTS
}

\author{
K. M. Abd El-Rahman ${ }^{{ }^{*}}$;Taie H.T. ${ }^{1}$; Soliman A.M. ${ }^{2}$ and Assem M.A.A. ${ }^{2}$ \\ 1Department of Animal Production, Faculty of Agriculture, University of \\ Menofya, Egypt. \\ 2 Department of Animal Nutrition Research, Animal Production Research \\ Institute, Dokki - Giza, Egypt.
}

A total number of eighty four New Zealand White (NZW) rabbits 5 weeks of age and $608 \pm 7.56 \mathrm{~g}$ average live body weight were allotted at random to seven similar experimental groups (of 12 rabbits each). Each group of rabbits was fed one of seven experimental pelleted diets (17\% crude protein and 12$13 \%$ crude fiber on average). The feeding trail extended for 9 weeks. The aim of the study was to investigate the effects of partial substitution (25 or 50\%) of soybean meal of control diet with different agro-industrial by-products as the sources for plant protein; rocket (RSM), fenugreek (FSM) and mustard seed meals (MSM) on growth performance, nutrients digestibility, blood constitutions, carcass characteristics and economic efficiency. Results indicated that, digestion coefficients of most nutrients and the nutritive values were significantly $(P<0.05)$ improved in the groups fed 25 or 50\% RSM and FSMdiet as compared to the control. The values of TDN increased by (4.85 and $4.52 \%$ ) for RSM, (4.44 and 4.43\%) for FSM and (1.80\%) for 50\% MSM. The DCP improvement was (9.13 and 2.04\%) for RSM, (2.44 and 7.25\%) for FSM, respectively. Replacing RSM, FSM or MSM by 25 or $50 \%$ in rabbit diets grew (9.85 and 4.58\%) for RSM, (3.36 and 7.56\%) for FSM and (1.23\%) for 25\% MSM faster than control. The diets containing 25 and $50 \%$ agro-industrial byproducts showed better $(P<0.05)$ values of feed conversion than the control diet. Serum total protein, albumin, globulin and urea- $N$ were significantly $(P<0.05)$ affected by different treatments; while, serum alanine aminotransferase (ALT), cholesterol and total lipids were not affected. Hot carcass weight and dressing percentages were significantly $(P<0.05)$ higher in the 25 and 50\% RSM, FSM or 25\% MSM groups than those of the control and 50\% MSM groups. Economical efficiency values of rabbits fed diets contained agro-industrial byproducts at marketing age (13 weeks) were higher than those of the control diet.

It could be concluded that substitution of rocket, fenugreek and mustard seed meals up to 50\% of soybean meal in the diet of NZW rabbits had good results without adverse effects on growth performance.

Key words: Rocket, Fenugreek, Mustard seed meal, Performance, Digestibility,

Blood constituents, Carcass characteristics, Rabbits. 
There is a shortage in animal protein in Egypt, rabbits could participate in solving this problem, but feed cost of rabbit production is still expensive. There are a large amount of crops, vegetables and fruit residues, which could be used as new sources of feedstuff with low price and high quality proteins to solve feed shortage and produce least cost diets for rabbits. Production of rocket in Egypt has been stead increased for the strong demand to volatile oils for pharmaceutical purpose. The rocket seeds contain carotenoids, vitamin $\mathrm{C}$, flavonoids such and sulfaraphene (Talalay and Fahey, 2001), volatile oils like myristicin, apiole $\beta$ - phellandrene (Bradley, 1992; Leung and Foster, 1996) and several biological activities including anticarcinogenic, antifungal, antibacterial plus their antioxidant action (Kim et al., 2004). They also contain $\mathrm{Zn}, \mathrm{Cu}, \mathrm{Fe}$ and other elements (Abdo, 2003) which increase immune response. After oil removal, rocket seed meal (RSM) could be used as a protein-rich meal for feeding rabbits with about $32 \%$ crude protein (ElNattat and El-Kady, 2007). Fenugreek (Trigonella foneum graecum L.), like other legumes is a good source of dietary protein (approximately 20- 30\%) for consumption by human and animals. The fatty acids from $5-10 \% ; 45-65 \%$ total carbohydrates with 15\% galactomanan (soluble fiber) (Schryver, 2002). It is reported to have anti-diabetics, anti-fertility, anti-cancer, anti-microbial, anti parasitic and hypochlosterolaemic effects (Al-Habori and Roman, 2002). Also, it contains some minerals and vitamins (Michael and Kumawat, 2003). Mustard is rich in proteins and other nutrients and could be used as animal feeds and feed additives. However, because of the presence of glucosinolates, whose hydrolytic products and other anti-nutritional substances are harmful, especially to non ruminant animals. MSM could not be widely used as animal feed (Francis et al., 2002). These products (RSM, FSM and MSM) are expected to increase in near future due to high demand of the extracted oil; consequently utilizing the byproduct may cause some environmental problems if not adequately utilized. When adequately supplemented, RSM may constitute a good vegetable protein source for use in rabbit diets in region where RSM is readily available and relatively inexpensive. RSM, FSM and MSM may be used to replace the imported SBM and in the main time reduces the cost of rabbits feeding.

The study reported herein was undertaken to investigate the effect of partial replacement of soybean meal instated of RSM, FSM and MSM (0, 25 and $50 \%$ ) on growth performance, digestibility and blood characteristics in growing New Zealand White (NZW) rabbits.

\section{MATERIALS AND METHODS}

\section{Animals and experimental design}

The present study was conducted on El-Gimaza Experimental station, Animal Production Research Institute, Agriculture Research and Animal Production Department, Faculty of Agriculture, Minufiya University, Egypt. 
The experiment was designed to evaluate the effects of partial substitution $(25$ or $50 \%)$ of soybean meal with different agro-industrial byproducts of rocket (Eruca sativa), fenugreek (Tigonella foenum-graecum) and mustard (Brassica juncea) meals (Table 1). Eighty-four males of growing NZW rabbits of 5 weeks old and $608 \pm 7.56 \mathrm{~g}$ average body weight, were distributed randomly and equally into seven treatments groups, each of 12 animals. Each group was sub- divided into four replicates with three animals each. Rabbits were housed in wire floor batteries of $60 \times 55 \times 40 \mathrm{~cm}$. All batteries were located in a naturally ventilated windowed house. All animals were kept under similar hygienic conditions. Rabbits were offered diets for duration of the feeding trial until reaching 13 weeks of age. Rocket, fenugreek and mustard seed meals were sprinkled and mixed with a solution of $2 \% \mathrm{Cu} \mathrm{SO}_{4}(500 \mathrm{ml} / \mathrm{kg})$ as reported by (Pailan and Singhal, 2003) then spreadsheets on a clean plastic sheet and sun dried for three days then meals were washed by water. Seven pelleted diets were prepared using rocket (RSM), fenugreek (FSM) and mustard seed meals (MSM) as a partial substitution of 25 or $50 \%$ soybean meal (SBM) of the control diet. Feed diets were nearly iso-nitrogenous and isocaloric and, also to the crude fiber percentages of the experimental diets nearly the same. Table 2 show feed ingredients and chemical analysis of the experimental diets.

Each group of rabbits was fed one of the seven experimental diets. Fresh water was automatically available at all times through stainless steel nipples for each cage. The experimental diets were offered to rabbits ad libitum. The rations were adjusted every week according to the average daily feed intake. Individual live body weight and feed intake were weekly recorded up to 13 weeks of age. Feed conversion ratio was calculated as $\mathrm{g}$ feed/g gain and as $\mathrm{g}$ $\mathrm{TDN} / \mathrm{g}$ gain.

Performance index (PI\%) was calculated according to North (1981) as below: PI = Live body weight $(\mathrm{kg}) \times 100 /$ Feed conversion. The economical efficiency was calculated by the following equation: $\mathrm{Y}=[(\mathrm{A}-\mathrm{B}) / \mathrm{B}]$, where $\mathrm{A}$ is selling cost of obtained gain and $\mathrm{B}$ is the feeding cost for this gain (Cited from El-Kerdawy, 1997).

Blood samples were individually collected at 13 weeks of age from each rabbit in non heparinized glass tubes to estimate blood parameters. Blood serum was separated by centrifugation at $3000 \mathrm{rpm}$ for 15 minutes. The collected serum was stored at $-18^{\circ} \mathrm{C}$ until analysis. At 14 weeks of age, a digestibility trial was done using three male animals per group.

\section{Chemical analyses:}

Chemical analysis of the tested diets and faeces were carried out according to AOAC (2000). Digestible energy (DE) of the experimental diets was calculated according by the equation described by Fekete and Gippert 
Table 1: Chemical analysis of feed stuffs of tested diets.

\begin{tabular}{|l|c|c|c|c|c|c|c|c|}
\hline \multirow{2}{*}{ Items } & \multirow{2}{*}{ DM\% } & \multicolumn{7}{|c|}{ Chemical analysis\% (DM basis) } \\
\cline { 3 - 9 } & & OM & CP & CF & EE & NFE & Ash & DE* \\
\hline Rocket seed meal & 90.12 & 94.16 & 32.34 & 9.80 & 6.20 & 45.82 & 5.86 & 2624 \\
\hline Fenugreek seed meal & 91.24 & 93.48 & 27.60 & 8.48 & 8.80 & 49.60 & 6.42 & 2666 \\
\hline Mustard seed meal & 90.25 & 92.65 & 38.83 & 11.67 & 6.79 & 35.36 & 7.35 & 2564 \\
\hline
\end{tabular}

Table 2: Feed ingredients and chemical analysis of the experimental diets.

\begin{tabular}{|l|c|c|c|c|c|c|c|}
\hline \multirow{2}{*}{\multicolumn{1}{|c|}{ Ingredients }} & \multirow{2}{*}{ Control } & \multicolumn{2}{c|}{ RSM } & \multicolumn{2}{c|}{ FSM } & \multicolumn{2}{c|}{ MSM } \\
\cline { 3 - 8 } & & $\mathbf{2 5 \%}$ & $\mathbf{5 0} \%$ & $\mathbf{2 5} \%$ & $\mathbf{5 0} \%$ & $\mathbf{2 5} \%$ & $\mathbf{5 0} \%$ \\
\hline Barley grain & 35 & 33.25 & 33.8 & 33.8 & 33.8 & 34.3 & 32.4 \\
Clover hay & 16.0 & 17.0 & 17.7 & 18.3 & 18.6 & 19.3 & 9.0 \\
Wheat bran & 16.9 & 13.15 & 10.6 & 10.6 & 9.6 & 7.85 & 15.75 \\
Soybean meal 44\% & 12.0 & 9.0 & 6.0 & 9.0 & 6.0 & 9.0 & 6.0 \\
Wheat straw & 8.2 & 8.2 & 8.1 & 8.15 & 8.15 & 8.15 & 11.45 \\
Yellow corn grain & 2.0 & 5.25 & 5.9 & 5.9 & 5.8 & 7.5 & 7.3 \\
Glutens meal & 3.25 & 4.25 & 4.85 & 3.0 & 6.0 & 4.0 & 5.2 \\
Rocket meal & --- & 3.0 & 6.0 & --- & --- & --- & -- \\
Fenugreek meal & --- & --- & ---- & 3.0 & 6.0 & --- & --- \\
Mustard meal & --- & --- & -- & --- & -- & 3.0 & 6.0 \\
Molasses & 3.0 & 3.0 & 3.0 & 3.0 & 3.0 & 3.0 & 3.0 \\
Di-calcium phosphate & 2.0 & 2.3 & 2.45 & 2.45 & 2.45 & 2.45 & 2.45 \\
Common salt & 0.5 & 0.5 & 0.5 & 0.5 & 0.5 & 0.4 & 0.4 \\
Lime stone & 0.7 & 0.95 & 0.4 & 0.4 & 0.4 & 0.4 & 0.4 \\
Premix* & 0.3 & 0.3 & 0.3 & 0.3 & 0.3 & 0.3 & 0.3 \\
Dl-Methionine & 0.15 & 0.15 & 0.15 & 0.15 & 0.15 & 0.15 & 0.15 \\
L-Lysine & --- & 0.1 & 0.2 & 0.1 & 0.15 & 0.1 & 0.1 \\
\hline Total & $\mathbf{1 0 0}$ & $\mathbf{1 0 0}$ & $\mathbf{1 0 0}$ & $\mathbf{1 0 0}$ & $\mathbf{1 0 0}$ & $\mathbf{1 0 0}$ & $\mathbf{1 0 0}$ \\
\hline Calculated analysis: & & & & & & & \\
\hline Crude protein & 17.1 & 17.1 & 17.1 & 17.0 & 17.1 & 17.0 & 17.0 \\
Crude fiber & 12.0 & 12.0 & 12.0 & 12.0 & 12.0 & 12.0 & 11.5 \\
Ether extract & 2.1 & 2.3 & 2.3 & 2.3 & 2.5 & 2.07 & 2.23 \\
Digestible energy k & 2500 & 2500 & 2495 & 2502 & 2499 & 2500 & 2499 \\
cal/kg (DE)* & & & & & & & \\
Calcium (\%) & 1.07 & 1.08 & 1.06 & 1.08 & 1.07 & 1.08 & 0.96 \\
Phosphorus & 0.77 & 0.78 & 0.78 & 0.79 & 0.77 & 0.77 & 0.78 \\
Cystine (\%) & 0.76 & 0.75 & 0.74 & 0.77 & 0.71 & 0.73 & 0.62 \\
Methionine (\%) & 0.41 & 0.41 & 0.45 & 0.46 & 0.41 & 0.40 & 0.40 \\
Methionine+Cystine (\%) & 0.70 & 0.67 & 0.69 & 0.67 & 0.66 & 0.65 & 0.65 \\
\hline
\end{tabular}

*Each one kilogram of premix contained: Vit.A 2000,000 IU, Vit. D3 150,000 IU, Vit. K $0.33 \mathrm{mg}$, Vit.B1 $0.33 \mathrm{~g}$, Vit. B2 $1.0 \mathrm{~g}$, Vit. B6 $0.33 \mathrm{~g}$, Vit. B12 $1.7 \mathrm{mg}$, Pantathonic acid $3.33 \mathrm{~g}$, Biotin $33 \mathrm{mg}$, Folic acid 0.83g, Choline chloride $200 \mathrm{mg}, \mathrm{Cu} 0.5 \mathrm{~g}$, I $16.6 \mathrm{mg}$ and Antioxidant $10.0 \mathrm{~g}$. 
(1986). Total protein, albumin, total lipids, cholesterol, aspartate aminotransferase (ALT) and urea-N concentrations in serum were estimated using commercial kits (Bio Merieux, France) according to the procedure outlined by the manufacturer.

\section{Statistical analysis:}

The data were statistically analyzed according to Snedecor and Cochran (1982) in one way analysis of variance design as the model:

$$
\mathrm{Y}_{\mathrm{ij}}=\mathrm{M}+\mathrm{A}_{\mathrm{i}}+\mathrm{e}_{\mathrm{ij}} \text {, }
$$

Where: $Y_{i j}=$ An observation, $M=$ Overall mean, $A_{i}=$ Effect of rations and $\mathrm{e}_{\mathrm{ij}}=$ Experimental error.

The significant differences between means were tested by using Duncan's multiple range test (Duncan, 1955).

\section{RESULTS AND DISCUSSION}

\section{Digestion coefficients:}

The effects of different levels are rocket (RSM), (FSM) and (MSM) seed meals on digestion coefficients values presented in Table 3. It could be noticed that feeding growing rabbits diets containing 25 and 50\% (RSM) or (FSM) were significantly $(\mathrm{P}<0.05)$ increased the digestibility of $\mathrm{DM}$ and $\mathrm{OM}$ compared with the other experimental groups. The digestion of $\mathrm{CP}, \mathrm{CF}, \mathrm{EE}$ and NFE of diets containing $25 \%$ RSM or FSM were significantly $(\mathrm{P}<0.05)$ higher than those fed (MSM) or control diet. This improvement in CP digestibility values of diets containing $25 \% \mathrm{RM}$ or FSM may be due to the higher proportion of soybean meal in these diets, while the improvement in $\mathrm{CF}$ digestibility coefficient values of the same diets may be due to increase energy intake. In this respect, rocket cake diet contains flavonoids such as carotenoids, vitamin $\mathrm{C}$ and isothiocyanate, which has anti-oxidant and antimicrobial effects. These ingredients as those of natural feed additives is beneficial for stimulation and activation of digestive system by improving digestibility of all nutrients. Ibrahim (2005) found that, crude fiber digestion percentage of rabbits receiving $1 \%$ of rocket seed as a supplement was significantly increased. This my be due to flavonoids and essential oils (Namur et, al. 1988 and Bradley, 1992). Zeweil et al. (2008) showed that rabbits fed $10.5 \%$ RSM- improved digestibility of DM by $4.4 \%$, OM by $4.7 \%$, CP by $4.4 \%$ and $\mathrm{CF}$ by $39.1 \%$.

\section{Nutritive values:}

The nutritive value of the experimental rations expressed as TDN, DCP are presented in Table 3. No significant differences among all tested diets except diets containing 25 and 50\% MSM and control rabbit diets caused a 
ABD EL RAHMAN et al.

Table 3: Digestion coefficients and nutritive values of the experimental rations.

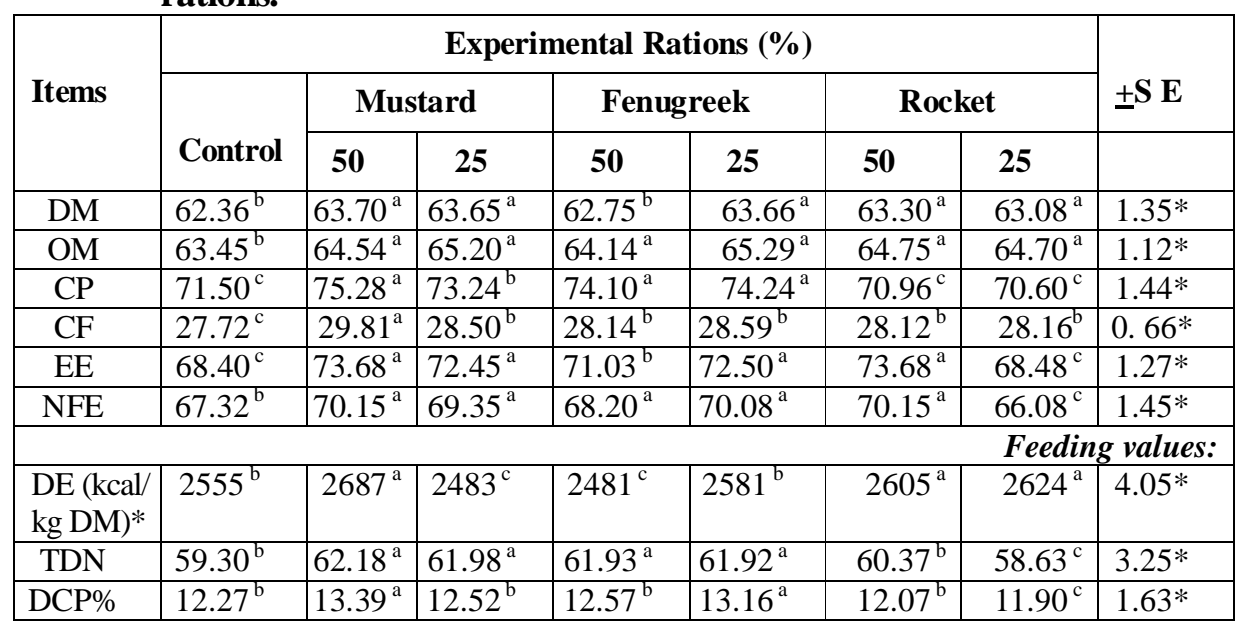

$+a, b$ and $c$ Means with different superscripts on the same row are different at $(\mathrm{P}<0.05)$.

significant $(\mathrm{P}<0.05)$ decrease in TDN and $\mathrm{DCP} \%$ compared with other diets. Increasing RSM and FSM levels from 25 to $50 \%$, significantly $(\mathrm{P}<0.05)$ increased TDN from $62.18 \& 61.98 \%$ for RSM and $61.93 \& 61.92 \%$ and DCP from $13.39 \& 12.52 \%$ for RSM to $12.57 \& 13.16 \%$ for FSM, respectively. In this respect, Zeweil et al., (2008) reported that, the nutritive values of this groups were more efficiently as the digested crude protein (DCP) increased by $2.8 \%$ and metabolizable energy (ME) by $4.3 \%$ in comparison with control). The group fed $21 \%$ RSM-diet was not significantly different from the control group in digestion coefficients of $\mathrm{CP}, \mathrm{CF}, \mathrm{EE}$ and NFE. Also, El-Tohamy and El-Kady (2007) mentioned that, digestibility of most nutrients were significantly $(\mathrm{P}<0.05)$ increased with rocket diet compared with control diet.

\section{Feed intake and feed conversion ratio:}

Results of the feeding trial are shown in (Table 4). Daily TDN intake and energy intake of rabbits fed 25 and $50 \% \%$ RSM or FSM diets showed significantly $(\mathrm{P}<0.05)$ higher values than those of the other diets. Also, introducing different levels of RSM or FSM significantly increased live body weight and daily weight gain. Obviously, rabbits fed RSM, FSM and MSM (25 or 50\%) grew (9.86 and $4.59 \%$ for rocket, 3.36 and $7.56 \%$ ) for fenugreek and (1.23 and $-2.04 \%)$ faster than control, respectively.

However, there were significant $(\mathrm{P}<0.05)$ differences among treatments in feed conversion ratio Table 4. Rabbits fed diets containing 25 and 50\% RSM or FSM were significantly $(\mathrm{P}<0.05)$ higher than those fed the other experimental diets. These results were similar to those obtained by EL-Nattat 
RABBITS FED ON SOME AGRO-INDUSTRIAL BY-PRODUCTS

Table 4: Performance of growing NZW rabbits fed diets containing rocket, fenugreek and mustard meal.

\begin{tabular}{|c|c|c|c|c|c|c|c|c|}
\hline \multirow{3}{*}{ Items } & \multicolumn{7}{|c|}{ Experimental Rations (\%) } & \multirow{3}{*}{$\pm \mathbf{S ~ E}$} \\
\hline & \multirow[b]{2}{*}{ Control } & \multicolumn{2}{|c|}{ Mustard } & \multicolumn{2}{|c|}{ Fenugreek } & \multicolumn{2}{|c|}{ Rocket } & \\
\hline & & 50 & 25 & 50 & 25 & 50 & 25 & \\
\hline No. of Animals & 12 & 12 & 12 & 12 & 12 & 12 & 12 & ----- \\
\hline Duration of trail, days & 63 & 63 & 63 & 63 & 63 & 63 & 63 & --- \\
\hline Av. Initial weight, $g$ & 604 & 624 & 625 & 574 & 624 & 602 & 603 & $7.56 \mathrm{~N}$ \\
\hline Av. Final weight, $g$ & $2087^{\mathrm{e}}$ & $2253^{\mathrm{a}}$ & $2176^{\mathrm{d}}$ & $2107^{\mathrm{c}}$ & $2219^{b}$ & $2078^{\mathrm{a}}$ & $2056^{\mathrm{f}}$ & 6. $16^{*}$ \\
\hline Total gain, g & $1483^{\mathrm{e}}$ & $1629^{a}$ & $1551^{\mathrm{c}}$ & $1533^{d}$ & $1595^{\mathrm{b}}$ & $1476^{\mathrm{e}}$ & $1453^{\mathrm{f}}$ & $3.27 *$ \\
\hline Av. Daily gain, g & 23.54 & 25.86 & 24.62 & 24.33 & 25.32 & 23.83 & 23.06 & $1.23^{*}$ \\
\hline $\begin{array}{l}\text { Av. DM intake, g } \\
\text { (DM basis): }\end{array}$ & $4971^{c}$ & $4979^{a}$ & $4971^{\mathrm{c}}$ & $5191^{\mathrm{a}}$ & $4962^{d}$ & $5025^{b}$ & $4948^{\mathrm{e}}$ & $3.624 *$ \\
\hline Av. TDN intake, $g$ & $2948^{d}$ & $3096^{\mathrm{b}}$ & $3081^{\mathrm{b}}$ & $3215^{\mathrm{a}}$ & $3072^{b}$ & $3033^{c}$ & $2901^{\mathrm{e}}$ & $3.012 *$ \\
\hline Av. DCP intake, $g$ & $610^{c}$ & $667^{\mathrm{a}}$ & $622^{b}$ & $652^{\mathrm{a}}$ & $653^{a}$ & $607^{\mathrm{c}}$ & $589^{d}$ & $1.82 *$ \\
\hline \multicolumn{9}{|l|}{ Feed conversion: } \\
\hline $\mathrm{Kg}$ DM/kg gain & $3.35^{\mathrm{a}}$ & $3.06^{\mathrm{d}}$ & $3.21^{\mathrm{b}}$ & $3.39^{\mathrm{a}}$ & $3.11^{\mathrm{c}}$ & $3.40^{\mathrm{a}}$ & $3.41^{\mathrm{a}}$ & $0.12 *$ \\
\hline $\mathrm{Kg}$ TDN/kg gain & $1.99^{\mathrm{ab}}$ & $1.90^{\mathrm{ab}}$ & $1.93^{\mathrm{ab}}$ & $2.07^{\mathrm{a}}$ & 1.87 & $2.02^{\mathrm{a}}$ & $2.00^{\mathrm{a}}$ & $0.315^{*}$ \\
\hline $\mathrm{Kg}$ DCP/kg gain & 0.41 & 0.40 & 0.40 & 0.43 & 0.41 & 0.41 & 0.40 & $0.02 \mathrm{NS}$ \\
\hline $\begin{array}{l}\text { Performance index } \\
\text { (PI \%) }\end{array}$ & $62.30^{c}$ & $73.63^{\mathrm{a}}$ & $67.79^{b}$ & $62.15^{\mathrm{c}}$ & $71.35^{\mathrm{a}}$ & 61.12 & $\underset{\mathrm{a}}{75.07}$ & $1.65^{*}$ \\
\hline
\end{tabular}

and ELKady (2007) indicated that 9\% RSM in the diet gave the best final body weight and feed conversion ratio compared to control.

These improvements may be attributed to the properties of this material that act not only as antibacterial, antiprotozoal and antifungal but also as antioxidant (Bradley, 1992; Leung and Foster, 1996). This incorporation of such non-conventional meals protein had no adverse effect on palatability and voluntary feed intake in rabbits. However, Rajendra et al. (2000) reported that mustard cake which belong to the same family of Eruca sativa could be used up to $30 \%$ of the rabbit diet without an adverse effect on broiler rabbit performance.

On the other hand, Abdo (2003) indicated that, the best values were for 0 and $25 \%$ substitution of soybean protein, while $50 \%$ substitution decreased both $\mathrm{BW}$ and BWG significantly $(\mathrm{P} \leq 0.05)$ when compared to the $0 \%$ substitution (without Eruca sativa seed meal). 
Performance index (PI\%):

The performance index results of rabbits fed rations with 25 and $50 \%$ of RSM, FSM and MSM showed significantly $(\mathrm{P}<0.05)$ higher values than those fed the diets containing 25\% FSM, MSM and control (Table 4). On the other hand, diets which contained 25 or $50 \%$ of RSM or $50 \%$ FSM and $50 \%$ MSM significantly $(\mathrm{P}<0.05)$ performance index values were increased by $(18.2$ and $8.8 \%)$ for RSM, (14.5\%), (20.5\%) for 50\% replacement of FSM and MSM, respectively than those of the control diet. These results were in agreement with the finding of Cheeke and Patton (1979) and Zaki El-Din (1996).

\section{Blood parameters:}

Data presented in (Table 5) illustrated that some metabolic enzymes such as aspartate aminotransferase (ALT) exhibited insignificant activities in rabbits fed diets containing two levels (25 or 50\%) of RSM, FSM or MSM which reflect a better function of liver. These results were agreement with finding of Zeweil et al. (2008) who, reported that GPT were not affected and can be concluded that rocket seed meal at $10.5 \%$ level of the diet in NZW rabbits had the best results without adverse effects on growth performance, kidney or liver function. Abdel - Azeem (2006) show that plasma GPT were decreased for groups fed fenugreek diets compared to those fed the control diet. Serum total protein, albumin and globulin were significantly $(\mathrm{P}<0.05)$ affected by the presence of rocket, fenugreek and mustard seed meal in rabbit diets. Zeweil et al. (2008) reported that, Serum total protein and albumin were significantly affected by the present of rocket seed meal in rabbit diets. In this respect, Habeeb et al., (1989) pointed that total serum protein concentration may be due to decrease of thyroxine production which stimulates the protein synthesis. Abdel-Azeem (2006) reported that supplementation of fenugreek into broiler diets increased plasma total protein, albumin and globulin. The broiler chicks fed fenugreek were superior $(\mathrm{P}<0.01)$ to these of broiler chicks fed the control diet. The majority of the increase on plasma total protein, albumin and globulin occurred at highest levels fenugreek.

Also, rabbits fed diets containing 25 and 50\% RSM, FSM or MSM showed slightly lower serum total lipids and cholesterol than those fed the other diets. These results were agreement with finding of Abdel-Azeem (2006) who showed that plasma total lipid and total cholesterol were decreased for broiler groups fed fenugreek diets compared to those fed the control diet. On the other side, Zeweil et al. (2008) reported that, Serum cholesterol were significantly affected by the presence of rocket seed meal in rabbit diets.

The significantly $(\mathrm{P}<0.05)$ increase of serum urea-N levels in rabbits fed diets containing 25 and 50\% RSM, FSM or MSM was within the normal range. The obtained results of urea- $\mathrm{N}$ levels indicated normal function of kidneys as reported by Habeeb et al., (1997) who reported that, serum urea 
RABBITS FED ON SOME AGRO-INDUSTRIAL BY-PRODUCTS

Table 5: Effect of feeding diets containing levels of the experimental diets on some blood parameters of growing NZW rabbits.

\begin{tabular}{|c|c|c|c|c|c|c|c|c|}
\hline \multirow{3}{*}{ Items } & \multicolumn{7}{|c|}{ Experimental Rations(\%) } & \multirow{3}{*}{$\pm \mathrm{S} \mathrm{E}$} \\
\hline & \multirow{2}{*}{ Control } & \multicolumn{2}{|c|}{ RSM } & \multicolumn{2}{|c|}{ FSM } & \multicolumn{2}{|c|}{ MSM } & \\
\hline & & 25 & 50 & 25 & 50 & 25 & 50 & \\
\hline ALT, (IU/l) & 25.54 & 26.72 & 25.84 & 25.61 & 25.52 & 26.03 & 26.42 & $0.86 \mathrm{NS}$ \\
\hline T. protein $(\mathrm{g} / \mathrm{d})$ & $7.15^{c}$ & $6.38^{\mathrm{a}}$ & $7.34^{\mathrm{b}}$ & $6.10^{\mathrm{a}}$ & $6.26^{\mathrm{a}}$ & $7.86^{c}$ & $7.06^{\mathrm{c}}$ & $0.58^{*}$ \\
\hline Albumin $(\mathrm{mg} / \mathrm{dl})$ & $4.75^{\mathrm{a}}$ & $2.73^{\mathrm{c}}$ & $4.88^{\mathrm{a}}$ & $3.09^{\mathrm{b}}$ & $3.06^{\mathrm{b}}$ & $4.74^{\mathrm{a}}$ & $5.22^{\mathrm{a}}$ & $0.72 *$ \\
\hline Globulin (mg/dl) & $2.40^{\mathrm{c}}$ & $3.65^{\mathrm{a}}$ & $2.46^{\mathrm{a}}$ & $3.01^{\mathrm{b}}$ & $3.20^{\mathrm{a}}$ & $3.08^{\mathrm{a}}$ & 2. $84^{\mathrm{c}}$ & $0.59^{*}$ \\
\hline Cholesterol (mg/dl) & 96.33 & 96.25 & 95.45 & 96.20 & 94.08 & 95.13 & $95.08^{c}$ & $1.65 \mathrm{NS}$ \\
\hline T. lipids (mg/dl) & 257.23 & 256.70 & 254.63 & 252.45 & 256.40 & 255.17 & 254.20 & $2.64 \mathrm{NS}$ \\
\hline Urea -N (mg/dl) & $15.56^{\mathrm{c}}$ & $16.73^{b}$ & $16.83^{b}$ & $15.81^{\mathrm{c}}$ & $15.81^{\mathrm{c}}$ & $17.05^{\mathrm{a}}$ & $17.94^{\mathrm{a}}$ & $0.08^{*}$ \\
\hline
\end{tabular}

$+a, b, c, \mathrm{~d}, \mathrm{e}$ and $\mathrm{f}$ Means with different superscripts on the same row are different at $(\mathrm{P}<0.05)$.

levels were 1.4 and $2.1 \mathrm{mg} / 100 \mathrm{ml}$, respectively, for NZW rabbits. Also, Zeweil et al. (2008) reported that, serum urea-N values were not affected. Otherwise, Abdel-Azeem (2006) show that plasma total lipid and uric acid were decreased for groups fed fenugreek diets compared to those fed the control diet.

\section{Carcass characteristic:}

Table (6) showed the carcass characteristics of slaughtered rabbits at 13 weeks of age. The differences in relative carcass traits as a results to the effect of feeding treatments were significantly $(\mathrm{P}<0.05)$. Under the condition of this experiment, it appears that, the highest values for dressing \% was recorded with rabbits fed diet containing 25 and 50\% RSM or FSM compare to those fed on the other diets. These treatments had the best digestion coefficients, which reflect on improving feed conversion and weight gain as previously mentioned in Table 2 and 3. The data was in agreement with those reported by Perez et al., (1991). Also, Gowda et al. (1996) mentioned that none of the carcass traits including percentage yield of edibles and in edibles were affected by dietary treatments except for a higher $(P<0.05)$ dressing percentage (65.1+or-1.61 vs. 59.9+or-1.09\%) in Angora rabbits fed on ureaammoniated deoiled mustard meal diet. On the contrary, Abdel - Azeem (2006) mentioned that, supplementation of fenugreek into broiler diets did not affect relative internal organs weight (liver, heart, spleen, bursa and pancreas). 
ABD EL RAHMAN et al.

Table 6: Dressing percentage and carcass offal's of slaughtered growing WNZ rabbits fed rations containing rocket, fenugreek and mustard seed meals.

\begin{tabular}{|c|c|c|c|c|c|c|c|c|}
\hline \multirow{3}{*}{ Items } & \multicolumn{7}{|c|}{ Experimental Rations(\%) } & \multirow{3}{*}{$\pm \mathrm{S} \mathrm{E}$} \\
\hline & \multirow[b]{2}{*}{ Control } & \multicolumn{2}{|c|}{ RSM } & \multicolumn{2}{|c|}{ FSM } & \multicolumn{2}{|c|}{ MSM } & \\
\hline & & 25 & 50 & 25 & 50 & 25 & 50 & \\
\hline Pre-slaughter wt,g & $2170^{d}$ & $2420^{\mathrm{a}}$ & $2280^{c}$ & $2340^{\mathrm{b}}$ & $2435^{\mathrm{a}}$ & $2200^{c}$ & $2075^{\mathrm{e}}$ & $4.15 *$ \\
\hline Dressed wt., g & $1155^{\mathrm{c}}$ & $1366^{\mathrm{a}}$ & $1263^{\mathrm{b}}$ & $1302^{\mathrm{a}}$ & 1350 & $1170^{\mathrm{c}}$ & $1059^{d}$ & $3.25 *$ \\
\hline$\%$ & $53.24^{b}$ & $56.45^{\mathrm{a}}$ & $55.40^{\mathrm{a}}$ & $55.60^{\mathrm{a}}$ & $55.44^{\mathrm{a}}$ & $53.18^{b}$ & $52.96^{\mathrm{c}}$ & $1.63 *$ \\
\hline Carcass wt., g & $1061^{\mathrm{b}}$ & $1218^{\mathrm{a}}$ & $1128^{\mathrm{a}}$ & $1173^{\mathrm{a}}$ & $1198^{\mathrm{a}}$ & $1083^{b}$ & $985^{\mathrm{c}}$ & $2.18 *$ \\
\hline$\%$ & $48.9^{\mathrm{a}} \mathrm{b}$ & $50.32^{\mathrm{a}}$ & $49.20^{\mathrm{a}}$ & $50.13^{\mathrm{a}}$ & $49.20^{\mathrm{a}}$ & $49.23^{\mathrm{a}}$ & 47.30 & $1.62 *$ \\
\hline Liver wt., $g$ & $105^{\mathrm{a}}$ & $107^{\mathrm{a}}$ & $96^{\mathrm{c}}$ & $105^{\mathrm{a}}$ & $90^{\mathrm{d}}$ & $100^{\mathrm{b}}$ & $80^{\mathrm{e}}$ & $1.85 *$ \\
\hline$\%$ & $4.84^{\mathrm{a}}$ & $4.42^{\mathrm{a}}$ & $4.21^{\mathrm{a}}$ & $4.49^{\mathrm{a}}$ & $3.70^{\mathrm{b}}$ & $4.55^{\mathrm{a}}$ & $3.86^{\mathrm{b}}$ & $0.07 *$ \\
\hline Kidney wt., g & $15.96^{\mathrm{a}}$ & $15.23^{\mathrm{a}}$ & $15.07^{\mathrm{a}}$ & $14.37^{\mathrm{b}}$ & $14.80^{\mathrm{b}}$ & 14.70 & $15.81^{\mathrm{a}}$ & $0.12 *$ \\
\hline$\%$ & 0.07 & 0.06 & 0.07 & 0.06 & 0.06 & 0.07 & 0.07 & $0.03 \mathrm{NS}$ \\
\hline Heart wt., g & $7.60^{\mathrm{b}}$ & $7.10^{\mathrm{b}}$ & $7.19^{\mathrm{b}}$ & $6.20^{\mathrm{c}}$ & $7.72^{b}$ & $6.17^{\mathrm{c}}$ & $8.52^{\mathrm{a}}$ & $0.86^{*}$ \\
\hline$\%$ & 0.03 & 0.03 & 0.03 & 0.03 & 0.03 & 0.03 & 0.04 & $0.02 \mathrm{NS}$ \\
\hline Giblets wt.,g & $128.55^{\mathrm{a}}$ & $129.33^{\mathrm{a}}$ & $118.26^{b}$ & $125.57^{\mathrm{a}}$ & $125.57^{\mathrm{b}}$ & $112.52^{\mathrm{c}}$ & $104.33^{d}$ & $2.78^{*}$ \\
\hline$\%$ & 5.92 & 5.34 & 5.19 & 5.37 & 4.62 & 5.49 & 5.03 & $0.78 \mathrm{NS}$ \\
\hline
\end{tabular}

$+\mathrm{a}, \mathrm{b}, \mathrm{c}, \mathrm{d}$ and e Means with different superscripts on the same row are different at $(\mathrm{P}<0.05)$.

\section{Economical efficiency:}

Accordingly, feed cost per kg gain and economical efficiency was better with diets containing rocket, fenugreek and mustard meals than those fed control diet Table 7. These results were due to mainly high price of weight gain which ranged between 36.33 and 40.73L.E. for diets containing oilseed meals with the price of daily weight gain of control 37.08 L.E. each. It was noticed that the cheaper in feed cost $/ \mathrm{kg}$ gain 13.90 and $13.86 \mathrm{L.E}$. for diets containing $50 \%$ rocket and mustard, while diet containing control was the highest of the other groups (15.20 L.E.). These results agree with finding with Rajendra et al. (2000) who mentioned that cost of feed input $/ \mathrm{kg}$ live weight gain was 12.64 L.E.for diet containing mustard cake vs. 14.05 L.E. for diet containing soybean meal and corresponding net return per animal was 29.1 vs. 26.5, respectively. Abdo (2003) mentioned that the economic efficiency of the 
RABBITS FED ON SOME AGRO-INDUSTRIAL BY-PRODUCTS

Table 7: Feed cost and economical efficiency of growing WNZ rabbits fed diets containing rocket, fenugreek and mustard meals.

\begin{tabular}{|c|c|c|c|c|c|c|c|c|}
\hline \multirow{3}{*}{ Items } & \multicolumn{7}{|c|}{ Experimental Rations(\%) } & \multirow{3}{*}{$\pm \mathrm{SE}$} \\
\hline & \multirow[b]{2}{*}{ Control } & \multicolumn{2}{|c|}{ RSM } & \multicolumn{2}{|c|}{ FSM } & \multicolumn{2}{|c|}{ MSM } & \\
\hline & & 25 & 50 & 25 & 50 & 25 & 50 & \\
\hline Live body wt. (g) & 2087 & 2253 & 2176 & 2107 & 2219 & 2078 & 2056 & --- \\
\hline Total feed intake (g) & 5629 & 5608 & 5605 & 5755 & 5621 & 5710 & 55.90 & --- \\
\hline Total weight gain $(\mathrm{g})$ & 1483 & 1629 & 1551 & 1533 & 1595 & 1476 & 14.53 & $\begin{array}{ll}-- \\
--\end{array}$ \\
\hline Feed cost (L.E.) & 15.20 & 14.13 & 13.90 & 14.50 & 13.94 & 14.39 & 13.86 & --- \\
\hline Price of wt. gain (L.E.) & 37.08 & 40.73 & 38.78 & 38.33 & 39.88 & 36.90 & 36.33 & --- \\
\hline Return & 21.60 & 26.60 & 24.88 & 23.83 & 25.94 & 22.51 & 22.47 & --- \\
\hline $\mathrm{EE} \% * * *$ & 1.44 & 1.88 & 1.79 & 1.64 & 1.86 & 1.56 & 1.62 & --- \\
\hline Relative E.E.\%*** & 100.0 & 130.6 & 124.3 & 113.9 & 129.2 & 108.3 & 112.5 & --- \\
\hline
\end{tabular}

* Based on free market prices of feed ingredients 2012, the cost of the experimental rations was estimated as the total prices of the ingredients used in the concentrate feed mixture, soybean meal, rocket, fenugreek and mustared meals, bearing, 2700, 3900, 180 L.E/ton., respectively,

** Prices of one kg body weight on selling 25.00 L.E.

*** Economical efficiency.

different formulated diets was affected by different treatments. The obtained results indicated that increasing Eruca sativa seed meal level decreased the price $/ \mathrm{kg}$ feed, but increased total feed cost $/ \mathrm{kg}$ weight gain by 101 and $111 \%$ of the control (0\% Eruca sativa seed meal) for 25 and 50\% substitution level, respectively.

In conclusion, from the previous results, rocket, fenugreek and mustard seed meals can be used up to $50 \%$ instead of soybean meal in the growing New Zealand rabbit diets improved the digestibility, daily weight gain, feed and economical efficiency, hot carcass weight and dressing percentage without any adverse effects on growth performance or kidney or liver function.

\section{REFERENCES}

A.O.A.C. (2000). Association of Official Analytical Chemist's. Official methods of Analysis. $16^{\text {th }}$ Edition, Washington, D.C. 
Abdel-Azeem, P. (2006). Effect of using fenugreek and fennel seeds as natural feed additives on performance of broiler chicks. Egypt. J. Nutr. Feeds, 9: 277-297.

Abdo, M.A. Zeinab (2003). Using Egyptian Eruca-Sativa seed meal in broiler ration with or without microbial phytase. Egypt. J. Nutr. and Feeds, (6) special Issue, 97-114.

Al-Habori, M. and A. Roman (2002). Pharmacological Properties In Fenugreek - The Genus Trigonella. $1^{\text {st }}$ End., by G.A. Petropoulos (Ed.)., Talor and Francis, London and New York, 10: 163 - 182.

Bradley, P.R (1992). British herbal medicine association. British herbal compendium, Rolnic zych., 1(434): 395-399.

Cheeke, P.R. and N.M. Patton (1979). The effect of fibre sources on growth and enteritis in rabbits an update. J. Appl. Rabbit. Res., 2: 3 - 5.

Delbanco, T.L. (1993). Unconventional medicine in the United States. Preference, cost and patterns of use. N. Engl. J. Med., 328: 246-252.

Duncan, D.B. (1955). Multiple range and multiple F. tests. Biometrics, 11:142.

El-Tohamy, M.M. and R.I. El-Kady (2007). Partial replacement of soybean meal with some medicinal plant seed meals and their effect on the performance of rabbits. International J. Agric. And Biol., 1560-8530-2215.

El-Kerdawy, M.A. (1997). Olive pulp as a new energy source for growing rabbits. Egyptian J. Rabbit Sci., 7 (1): 1 - 12.

EL-Nattat W.S. and EL-Kady R.I. (2007). Effect of Different Medicinal Plant Seeds Residues on the Nutritional and Reproductive Performance of Adult Male Rabbits. Int. J. Agri. Biol., 9 (3), 2007.

Fekete, S. and T.Gippert (1986). Digestibility and nutritive value of nineteen feedstuffs. J. Appl. Rabbit Res., 9: 103 - 108.

Francis, F., G. Lognay, J.-P. Wathelet and E. Haubruge, (2002). Characterisation of Aphid Myrosinase and Degradation studies of Glucosinolates. Archives of insect biochemistry and physiology, 50: 73-182.

Gowda S.K.; R.C. Katiyar, V.R. Sasty and D.k. Agrawal (1996). Meat potential of Angora strain rabbits on different vegetable protein supplements. Indian J. Anim. Nutr., 13: 113-7.

Habeeb, A.A.M.; A.F.M. Mare; A.M. El-Maghawry and A.E.Gad (1997). Growing rabbits as affected by salinity in drinking water under winter and hot summer conditions of Egypt. Egyptian J. Rabbit Sci., 7 (2): 81 -94 . 
Ibrahim, S.A.M.(2005). Effect of some medicinal plants as feed additives on growth and some metabolic changes in rabbits. Egypt J. Nutr. Feeds, 8: $207-19$

Kim,S.J. ,Jin,s .and Ishii G. (2004). Isolation and structural elucidation of 4(B-d- lucopyranosyldisulfanyl) butyl glucosinolate from leaves of rocket salad (Eruca sativa L) and its antioxidative activity Biosci. Biotechnology, 68 : 2444- 2450

Leung, A.Y.; and S. Foster (1996). Drugs And Cosmetics, 2 nd Encyclopedia of common Natural ingredients used in food New York: john wiley \& sons, Inc.

Michael, D. Anderson and D. Kumawat (2003). Legend and archeology of fenugreek, constitutions and modern applications of fenugreekseeds. International symp., USA., PP: $41-42$.

Namur, A.P.; J. Morel and H. Bichek (1988). Compound animal feed and feed additives. In Deboer, F., H. BICHEL, Eds. Livestock feed resources and feed evaluation in Europe. Elsevier. Science publ., Amsterdam.

Pailan, G.H. and K.K. Singhal (2003). Effect of chemical treatment of mustard - cake on its palatability and degradation of glucosinolates. Indian J. Anim. Sci., 73:428-431.

North, M.O. (1981). Commercial Chicken Production. $2^{\text {nd }}$ Edition, AV., Publishing Company I.N.C., Westpost Connecticut, USA.

Perez, P.; M.J., Fraga; R.Carabano and J.C. de Blas (1991). Effect of fibre source on diet digestibility and growth in fattening rabbits. J. Appl. Rabbits. Res., 14: 159 - 165.

Rajendra Prasad; Sankhyan, S. K . and Karim, S. A.( 2000). Utilization of different protein supplements in the diet of broiler rabbits. Indian Journal of Animal Sciences, 70: 12, 1266-1267.

Schryver, T. (2002). Fenugreek, Total Health, 24: 42 - 44.

Snedecor, G.W. and Cochran, W.G. (1982). Statistical Methods $.6^{\text {th }}$ Edition. Iowa State University Press. Ames. U.S.A.

Talalay P., and Fahey J.W. (2001). Phytochemicals from crucierous plants protect against cancer by modulating carcinogen metabolism. J. Nutr., 131: 3027-3033.

Zaki El-Din, M. (1996). Effects of source and level of dietary fibre on growth, nutrient digestibility and carcass characteristics of rabbits. Egypt. Poultry Sci. J., 16 (11): 221 - 238.

Zeweil H.S; Ahmed, M.H.; M.M.El-Adawy and B. Zaki (2008). Effect of substitution rocket seed meal as a source of protein for soybean meal in diets of New Zealand White rabbits. 9th World Rabbit Congress June 10-13, 2008 - Verona - Italy. 


\title{
أداء الأرانب النامية المغذاة على بعض نواتج التصنيع الزراعي
}

\author{
كمال محمد عبد الرحمن* ـ حمدي توفيق طايع* ـ أحمد على محمد سليمان**ـ

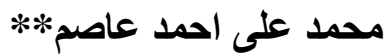

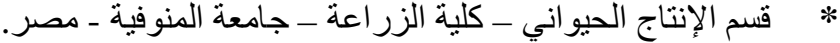 \\ *** معهد بحوث الإنتاج الحيو اني - مركز البحوث الزراعية - جيزة - مصر.
}

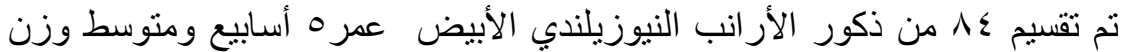

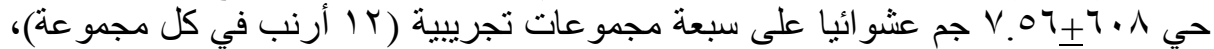

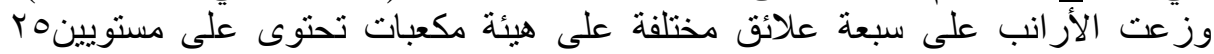

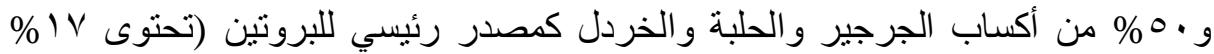

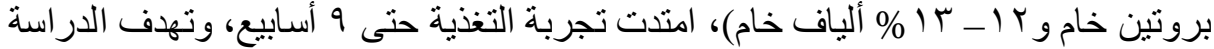

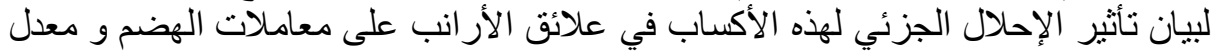

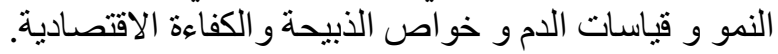

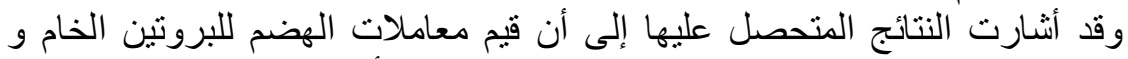

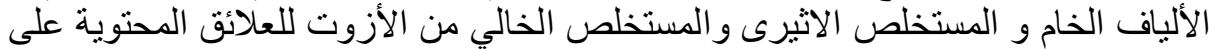

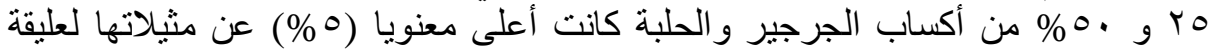

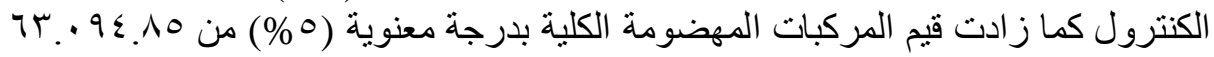

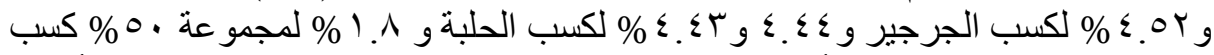

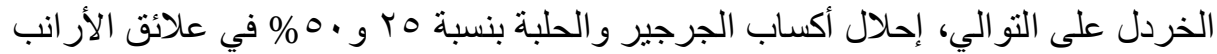

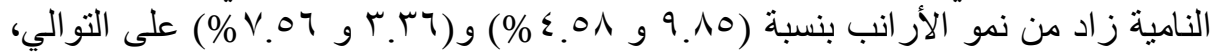

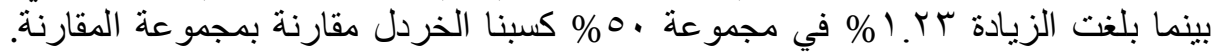

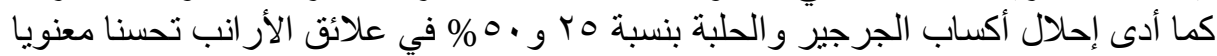

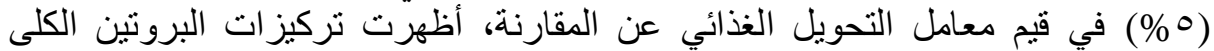

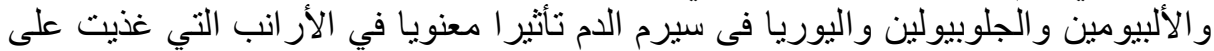

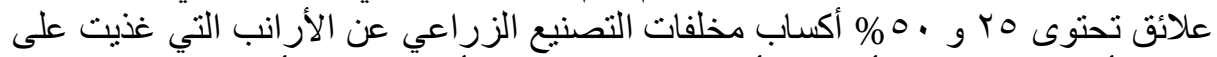

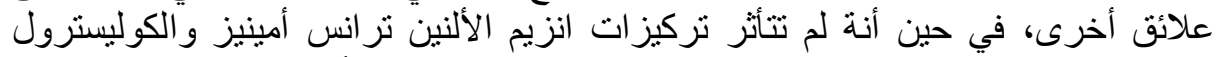

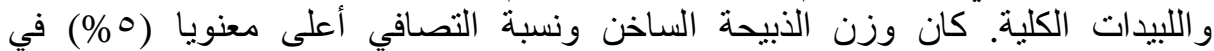

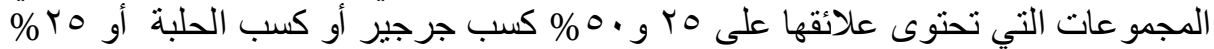

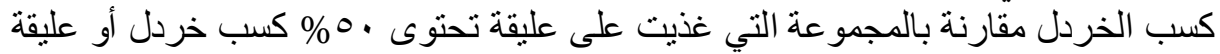

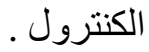
التوصية: نستنتج أنة يمكن إحلال أكساب الجرجير و الحلبة و الخردل محل كسب فول

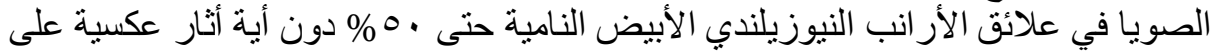

